IZA DP No. 8295

Non-Farm Enterprise Productivity and

Spatial Autocorrelation in Rural Africa:

Evidence from Ethiopia and Nigeria

Nkechi S. Owoo

Wim Naudé

June 2014 


\title{
Non-Farm Enterprise Productivity and Spatial Autocorrelation in Rural Africa: Evidence from Ethiopia and Nigeria
}

\author{
Nkechi S. Owoo \\ University of Ghana \\ Wim Naudé \\ MsM, Maastricht University, UNU-MERIT \\ and IZA \\ Discussion Paper No. 8295 \\ June 2014 \\ IZA \\ P.O. Box 7240 \\ 53072 Bonn \\ Germany \\ Phone: +49-228-3894-0 \\ Fax: +49-228-3894-180 \\ E-mail: iza@iza.org
}

\begin{abstract}
Any opinions expressed here are those of the author(s) and not those of IZA. Research published in this series may include views on policy, but the institute itself takes no institutional policy positions. The IZA research network is committed to the IZA Guiding Principles of Research Integrity.

The Institute for the Study of Labor (IZA) in Bonn is a local and virtual international research center and a place of communication between science, politics and business. IZA is an independent nonprofit organization supported by Deutsche Post Foundation. The center is associated with the University of Bonn and offers a stimulating research environment through its international network, workshops and conferences, data service, project support, research visits and doctoral program. IZA engages in (i) original and internationally competitive research in all fields of labor economics, (ii) development of policy concepts, and (iii) dissemination of research results and concepts to the interested public.
\end{abstract}

IZA Discussion Papers often represent preliminary work and are circulated to encourage discussion. Citation of such a paper should account for its provisional character. A revised version may be available directly from the author. 


\section{ABSTRACT \\ Non-Farm Enterprise Productivity and Spatial Autocorrelation in Rural Africa: Evidence from Ethiopia and Nigeria}

The productivity of non-farm enterprises in rural Africa may be associated with the productivity of other spatially proximate farm and non-farm enterprises. To test for the presence and significance of such spatial autocorrelation we use data from the georeferenced 2011 Ethiopian Rural Socioeconomic Survey (ERSS) and the 2010/2011 Nigeria General Household Survey (NGHS). We find evidence of significant spatial autocorrelation. Productivity of non-farm enterprises is widely dispersed across space in both countries. In Ethiopia rural non-farm enterprises are more productive in locations where farms are less productive. In Nigeria, we find evidence for spatial autocorrelation at the individual enterprise level but not at the community level, once we control for location variables. Hence, taking spatial autocorrelation into account using spatial lag and spatial error models, we find education, age, size of the household, religious affiliation and community infrastructure are significant determinants of the labour productivity of non-farm enterprises in Ethiopia and Nigeria. This is the first time, to the best of our knowledge, that the productivity of rural nonfarm enterprises in Africa has been studied in this way.

JEL Classification: L26, C21, M13, O55

Keywords: entrepreneurship, Africa, rural development, agriculture, spatial autocorrelation, Ethiopia, Nigeria

Corresponding author:

Wim Naudé

Maastricht School of Management

PO Box 1203

6201 BE Maastricht

The Netherlands

E-mail:w.naude@maastrichtuniversity.nl 


\section{Introduction}

Non-farm enterprises ${ }^{1}$ are ubiquitous in rural Africa. Around 42 percent of rural households in a recent survey in Africa operated non-farm enterprises (Nagler and Naudé, 2014a) and between 40 and 50 percent of rural household income in Africa are estimated to be from rural non-farm enterprises (Rijkers and Costa, 2012; Haggblade et al., 2010). Growth in rural populations, declines in agricultural employment, and rising demand for higher-value added farm products amongst a rising middle class in Africa is making the non-farm economy increasingly vital for job creation, livelihoods and stability (De Brauw et al., 2013; Rijkers and Costa, 2012; Janvry and Sadoulet, 2010).

Despite this, there are glaring gaps in the scholarly literature on these rural non-farm enterprises. Scholars have studied the push and pull factors that determines whether and when rural households start non-farm enterprises (e.g. Nagler and Naudé, 2014a; Reardon et al., 2006; Rijkers and Söderbom, 2013). They have also attained a fairly good grasp on the impact of non-farm enterprises on rural poverty and employment (e.g. Barrett et al., 2001; Fox and Sohnesen, 2013). The gap however is on the performance of non-farm enterprises in Africa (Rijkers et al., 2010). The literature has so far very little to say on potentially important aspects of non-farm enterprises, such as how productive they are, or what the factors are that determines their productivity and survival. Apart from Nagler and Naudé (2014b), to the best of our knowledge we are not aware of any previously published study in Africa that satisfactorily contributes to our knowledge in this regard (the closest being perhaps Rijkers et al., 2010). This is a serious omission: if the survival, growth and job creation of non-farm enterprises depend on their performance, then a rigorous understanding in this regard will have potentially important policy implications.

In this paper we make a modest contribution toward filling this knowledge by providing empirical evidence on the productivity on rural non-farm enterprises in Ethiopia and Nigeria. Moreover, we do so using spatial econometric methods, for first time to the best of our knowledge that this is done in the context of rural household enterprises in Africa. This allows us to take into consideration the fact that patterns of non-farm productivity will be dispersed not only between various types of non-farm enterprises, but also across geographical space. If spatial autocorrelation is significant in rural Africa then failure to account for these may result in biased coefficients and inference problems (Anselin and Griffin, 1988).

The rest of the paper will proceed as follows. Section 2 summarizes the relevant literature. Section 3 outlines the data and provides an exploratory analysis of the spatial patterns of rural non-farm and farming activities in Ethiopia and Nigeria. The regression estimation strategy and results are presented and discussed in Section 4. Section 5 concludes.

\section{Relevant Literature}

In the literature on firm performance in developing countries, and specifically Africa, most of the attention has been on measures of firm sales and employment growth (see

\footnotetext{
${ }^{1}$ The term rural non-farm enterprises is used in this paper to refer to all rural business enterprises outside of farming; it includes for example shops, business services, transport (taxi's), food processing and preparation, and construction amongst others (see e.g. Haggblade at al., 2010).
} 
e.g. Nichter and Goldmark, 2009). Relatively fewer studies have dealt with productivity as a measure of performance. Productivity is however one of the most important measures of performance as it reflects how efficiently the firm turns inputs into outputs. The most commonly used measures are total factor productivity (TFP) and partial measures such as output or revenue per worker. As Nagler and Naudé (2014b) also mentions, the patterns and determinants of firm-level productivity have generated a large literature, mainly using data from advanced economies. A recent survey is provided by Syverson (2011). In this literature, the interest on the productivity of firms are based on the realization that more productive firms are more likely to survive and to grow, create jobs, and innovate (see also e.g Wennberg and Lindqvist, 2010). In Africa, Frazer (2005) found evidence from Ghanaian manufacturing enterprises that more productive enterprises are less likely to fail.

Productivity levels are however widely dispersed across firms ${ }^{2}$ and this has begged the question why. Key determinants that have been identified include managerial competence (Mano et al., 2012; Bloom and Van Reenen, 2010); the skills and education of a enterprise's workers (Moretti, 2004); innovation and use of technology (Bernard et al., 2010); experience and learning-by-doing (Van Biesebroeck, 2005) and external shocks (Rijkers and Söderbom, 2013).

Productivity levels are also widely dispersed across space. This reflects the fact that the productivity of a firm also depends on the productivity of other firms in close proximity - distance and clustering matters. One reason is that 'knowledge spills over quickly' (Mano et al., 2012:466). Similarly, productive firms tend to cluster together, not only due to less productive firms benefitting from localization economies such as the spilling over of knowledge and technology (Bloom et al., 2013; Martin et al., 2011) and from horizontal linkages (Nichter and Goldmark, 2009) but also because the competitiveness of highly productive firms tend to push less productive firms in the same industry out of the market (Foster et al., 2008; Ali and Peerlings, 2011).

The spatial clustering of firms, and the agglomeration benefits it confers on them, have long been studied in regional science and in geographical economics (e.g. Fujita et al., 1999), wherein the clustering of many firms in close geographic proximity generated localization and urbanization economies (Martin et al., 2011). The former is associated with labour-market pooling, and knowledge spill-over effects within specific industries, and the latter with the benefits of a diverse and more competitive business environment and ore support services. The vast bulk of studies in this regard has been dealing with advanced economies, and has found spatial autocorrelation significant and attached much value to the clustering of firms in geographic space.

For example Wennberg and Lindqvist (2010) study 4397 Swedish firms and find that firms that are located in stronger clusters are more likely to survive, and additionally create more jobs and pay their workers higher wages. Rupasingha and Contreras (2010) study the determinants of regional variation in microenterprises in rural areas using county-level information on the U.S. and use spatial lag and error model specifications to control for the observed spatial dependence in the data. They argue that the significant spatial parameters observed are indicative of spill-over effects in the data. Baumgartner et al (2012) use spatial random effects model to find evidence of spatial spill-over effects

2 See Nagler and Naudé (2014b); Productivity levels are also dispersed across countries; the literature suggests that productivity of firms in African countries are on average lower than that of firms elsewhere (Nichter and Goldmark, 2009). 
on local entrepreneurial activities in rural Switzerland. Martin et al. (2011) use a panel dataset of French firms and find evidence that spatial spill-over effects are significant, and that clustering increases firms' productivity, mainly due to localization economies.

Deller (2010) employs a Geographical Weighted Regression (GWR) to examine whether the role of microenterprises in economic growth varies over space in the USA. The advantage of the GWR technique is that instead of the traditional assumption that a variable has the same influence over all locations, this method of spatial enquiry allows the explanatory variables to have differential effects across geographical space. The author finds that although microenterprises have a positive role in explaining growth in the eastern and central regions of the USA, they have a dampening effect in the Coastal Pacific regions.

Steinberg et al. (2010) examine the influence of rural social networks on the success of ethnic-owned businesses in Mendocino County, California, using public participation GIS (PPGIS). The latter was used to map business locations, industry clusters, community engagement points and gender and ethnicity of study participants and from these, participants of the study were asked to indicate locations where they were particularly active. This facilitated observance of how involved participants were in their communities. Results indicated that ethnic entrepreneurs received more support and membership in these business networks was associated with more years of profits.

Despite the varied empirical techniques employed in the above mentioned studies, they have concurred that spatial effects do appear to matter for enterprise performance and growth (in developed countries). As mentioned, fewer spatial studies of rural non-farm enterprise creation and performance have been conducted in developing countries. This is despite the fact that in developing countries the importance of clustering and spatial proximity for firm performance has been acknowledged.

In Africa for instance, McCormick (1999: 1532) has argued that spatial proximity between firms in Africa would have positive impacts on their productivity due to 'poor infrastructure, weak information systems, and cultures that place high value on face-toface communication'. And according to Siba et al. (2012:2) '...spillovers and other externalities may have large effects on firm performance in this environment, since most firms operate far away from the best practice frontier, implying considerable scope for learning'.

Consistent with the aforementioned, Ali and Peerlings (2011) finds evidence from the handloom industry in Ethiopia that clustering can help micro enterprises to improve their productivity. Ayele et al. (2009) examine the importance of clustering in the rural non-farm sector in Ethiopia, and its impact on productivity. Without explicitly employing spatial econometric techniques, they investigate the presence of spill-over effects among a concentration of handloom weavers in the country and find that clustering helps to improve productivity through shared workspaces, for instance, especially in the absence of adequate financial resources. Siba et al. (2012), also using data from Ethiopia finds that spatial proximity of enterprises to other enterprises in the same industry improves their productivity, and reduces the price of their products. Their results imply that Ethiopian clusters did not form endogenously because enterprises would like to avoid the price-reducing effects of competition from similar firms.

Despite the recognition of the importance of spatial clustering and spatial autocorrelation for the productivity of firms in Africa, relatively few studies have examined the nature 
and importance of spatial spill-over effects on firms, and none of which we are aware of has yet examined the productivity of non-farm enterprises including the impact of spatial spill-over effects on productivity. As we mentioned in the introduction, the prior study that comes closest to ours is Rijkers et al (2010) who study the performance of non-farm manufacturing enterprises in rural Ethiopia and compare their performance with than of urban manufacturing enterprises. They find that enterprise productivity is more dispersed in rural than urban Ethiopia, and that urban enterprises are more productive than rural enterprises. For instance, using output per labour as a productivity measure they calculate an output: labour ratio for enterprises in remote rural areas as 0.43 , in rural towns as 0.95 and in urban areas as 2.30 (Rijkers et al., 2010:1282). They conclude that proximity matters for enterprise productivity, and imply that spatial spill-over effects may be important, concluding that for rural enterprises '...even limited interaction is likely to lead to substantial increases in efficiency'(p. 1291).

They do not however test explicitly for spatial spill-over effects or spatial autocorrelation as a factor in enterprise productivity in Africa. So far, this has been, to the best of our knowledge, neglected in Africa. The study that comes closest to ours in terms of methodology and focus is by Gibson and Olivia (2010) who uses spatial econometric methods to study household decision-making, not in Africa, but in rural Indonesia. Using spatial lag and spatial error models they find spatial autocorrelation to be significant and conclude that the effect of location infrastructure is less important in Indonesia once underlying spatial autocorrelation is controlled for. Gibson and Olivia, (2007; 2010) also find that that in Indonesia rural non-farm enterprise performance is affected by for instance marital status, social and cultural capital, and the local business climate as reflected in the availability of amenities and infrastructure such as good roads, credit facilities, electricity of and education levels of the head of the household (Gibson and Olivia, 2007; 2010; see also Rupasingha and Contrera; 2010 and Ali et al., 2010).

In the remainder of this paper we provide a more rigorous investigation of the factors that influence rural non-farm enterprise productivity using data on Ethiopia and Nigeria, in addition to the spatial dynamics of rural non-farm enterprise performance in both countries. Spatial econometric techniques are employed to examine the evidence for spatial dependence in the data.

\section{Data and Methods}

\subsection{Data}

We use data from the 2011 Ethiopian Rural Socioeconomic Survey (ERSS) and the 2010/11 Nigeria General Household Survey (NGHS). About 83 per cent of Ethiopia's population is rural (ESSP-II, 2009). In addition to information on basic demographics such as education, health, labour, time-use and non-farm economic activities, the data also include geographical information at the enumeration area (EA) level, which facilitates spatial analyses. To measure rural non-farm enterprise performance we use the enterprise output per worker. This is a commonly used measure of productivity, although it must be recognised that it is a partial measure and not ideal (see Syverson, 2011). Better would have been to derive estimates of total factor productivity (TFP); however due to data limitations this is not feasible in the present instance. For a further discussion on problems of measuring productivity in the African firm-context, see Frazer (2005). 
The ERSS and NGHS also contain community-based information such as social and physical infrastructure. Detailed information is also collected on farming activities in both countries, in addition to information on animal holdings and related costs.

The ERSS sample is representative of rural areas and small towns in Ethiopia. A total of 290 rural areas and 43 small towns were included in the survey, making up a total sample size of 333 enumerator areas available for this research. Each enumerator area is made up of about 12 households. The NGHS is made up of 411 enumerator areas. Given that geo-referenced information is available at the enumerator area level in both countries, the data are aggregated accordingly and the analyses are performed at the enumerator area level.

It is important to state upfront that performing the analyses at this aggregated level is a disadvantage of this study as the number of observations is significantly reduced. Additionally, given that spatial interactions and influences are more likely to take place at the individual, person-to-person level, it would be more appropriate to perform the analyses at this localized scale.

Although GIS information is available only at the enumerator area level, the spatial analyses may still be conducted at the localized level by a random assignment of the GIS information to individual household heads within a given enumerator area. This would allow a richer analysis of rural non-farm productivity using individual-level data, although it should be noted that any spatial relationships must be interpreted with caution as these may have been artificially created by the random allocation of georeferenced information. ${ }^{3}$

\subsection{Descriptive Statistics}

Basic descriptive statistics are provided in Table 1A for Ethiopia and Table 1B for Nigeria. This includes both household level variables (comprising characteristics of the household head) and community level variables, which are common to each household in the enumerator area ${ }^{4}$. In order to examine the performance and productivity of non-farm enterprises in both countries, the sample is restricted to those enumerator areas where rural households are operating non-farm enterprises.

Due to missing information on the dependent variable (sales of rural non-farm enterprises over the past 12 months, there are 259 (from 333) observations or enumerator areas for Ethiopia and 379 (from 411) observations for Nigeria. An implication of the relative small sample size is that the probability of finding significant results is minimized in this study.

\footnotetext{
${ }^{3}$ Results from this individual-level analysis are reported in Table 4A and Table $4 \mathrm{~B}$ for Ethiopia and Nigeria, respectively

${ }^{4}$ Scanty data on religion of household heads and cooperatives in Nigeria
} 
Table 1A: Summary Statistics (Ethiopia)

\begin{tabular}{|c|c|c|c|c|c|}
\hline Variable & Observations & Mean & Standard Deviation & Min & $\operatorname{Max}$ \\
\hline \multicolumn{6}{|l|}{ Dependent Variable } \\
\hline Sales over past 12 months $(\log )^{\mathrm{a}}$ & 259 & 5.678 & 1.462 & 2.01 & 9.798 \\
\hline \multicolumn{6}{|l|}{ Household Characteristics } \\
\hline Age of household head & 259 & 40.918 & 9.088 & 22 & 87 \\
\hline Male household head & 259 & 0.755 & 0.276 & 0 & 1 \\
\hline Married household head & 259 & 0.763 & 0.279 & 0 & 1 \\
\hline Educated household head & 259 & 0.453 & 0.351 & 0 & 1 \\
\hline Muslim household head & 259 & 0.316 & 0.437 & 0 & 1 \\
\hline Household size & 259 & 5.025 & 1.690 & 1 & 11.67 \\
\hline \multicolumn{6}{|c|}{ Location and Infrastructure Characteristics } \\
\hline \multicolumn{6}{|c|}{ Presence of cooperative in community } \\
\hline Access to phone & 259 & 0.363 & 0.482 & 0 & 1 \\
\hline Presence of microfinance institution & 259 & 0.317 & 0.466 & 0 & 1 \\
\hline Distance to asphalt road b & 259 & 54.556 & 77.536 & 0 & 675 \\
\hline Distance to market ${ }^{\mathrm{b}}$ & 259 & 67.293 & 50.115 & 3.9 & 282.65 \\
\hline
\end{tabular}

${ }^{\mathrm{a}}$ in Birr, ${ }^{\mathrm{b}}$ in Kilometres

Table 1B: Summary Statistics (Nigeria)

\begin{tabular}{|c|c|c|c|c|c|}
\hline Variable & Observations & Mean & $\begin{array}{l}\text { Standard } \\
\text { Deviation }\end{array}$ & Min & $\operatorname{Max}$ \\
\hline \multicolumn{6}{|l|}{ Dependent Variable } \\
\hline Sales over past 12 months $(\log )^{\mathrm{a}}$ & 379 & 8.766 & 1.020 & 4.605 & 13.261 \\
\hline \multicolumn{6}{|l|}{ Household Characteristics } \\
\hline Age of household head & 379 & 49.744 & 6.769 & 34.2 & 68.3 \\
\hline Male household head & 379 & 0.843 & 0.169 & 0.2 & 1 \\
\hline Married household head & 379 & 0.802 & 0.181 & 0.2 & 1 \\
\hline Educated household head & 379 & 0.027 & 0.066 & 0 & 0.5 \\
\hline Muslim household head & - & - & - & - & - \\
\hline Household size & 379 & 5.530 & 1.562 & 1.9 & 11.4 \\
\hline \multicolumn{6}{|l|}{$\begin{array}{l}\text { Location and Infrastructure } \\
\text { Characteristics }\end{array}$} \\
\hline Presence of cooperative in community & - & - & - & - & - \\
\hline Access to phone & 379 & 0.327 & 0.470 & 0 & 1 \\
\hline Presence of microfinance institution & 379 & 0.232 & 0.423 & 0 & 1 \\
\hline Distance to asphalt road b & 379 & 13.769 & 16.571 & 0.02 & 100.5 \\
\hline Distance to market ${ }^{\mathrm{b}}$ & 379 & 64.916 & 42.554 & 0.93 & 214.26 \\
\hline
\end{tabular}

The dependent variable, reflecting rural non-farm enterprise performance and productivity, is measured as the logged value of total sales of enterprises in the past 12 months per the total number of workers- both family and employed workers- in order to control for size effects.

The average age of a household head is about 41 years in Ethiopia and about 50 years in Nigeria; and male heads make over three-quarters of the sample in both countries. Older male heads are expected to be associated with higher performing rural non-farm enterprises given that they may be more knowledgeable and experienced. A similar proportion (over 75\%) of all household heads (male and female) are married in both countries, while almost half of household heads report that they have attended school in Ethiopia $^{5}$. Education is typically associated with higher performance in rural non-farm enterprises given that more educated entrepreneurs may be able to employ more efficient

${ }^{5}$ Due to lack of data, current educational status is used as a proxy in Nigeria 
techniques of production, and may be aware of and therefore able to take advantage of greater opportunities for enterprise improvements such as credit facilities, among others.

In the sample, Muslims make up about a third of the population in Ethiopia, while the average household size in each enumerator area is about 5 people in both countries, although slightly higher in Nigeria. The maximum household size in both countries is about 11 people.

In terms of community infrastructure, 17 per cent of enumerator areas have a cooperative present in their communities, while over a third of respondents in both countries have access to phones. A third of all EA's in Ethiopia report the presence of a microfinance institution in their community, while only about a fifth of communities in Nigeria have access to microfinance institutions.

The average distance to a tarred/ asphalt road is about $54 \mathrm{~km}$, and ranges from 0 to as many as $675 \mathrm{~km}$ in Ethiopia. In Nigeria, this distance is considerably smaller. The average distance to a tarred road is about $14 \mathrm{~km}$, and ranges from 0 to $100 \mathrm{~km}$. This may be due to the fact that the Nigerian dataset includes some urban communities. The average distance to the nearest large weekly market is quite similar in both countriesabout $65 \mathrm{~km}$. The information on social infrastructure is obtained from the communitylevel surveys where a reputed member of the society is asked a series of these community-specific questions. The presence of physical infrastructure has been observed to have a positive impact of rural non-farm enterprise performance in other research studies.

\subsection{Exploratory Spatial Data Analysis}

If we measure the productivity of rural non-farm enterprises as output (sales) per worker made (in Ethiopian Birr and Nigerian Naira) by these enterprises in the previous year, then we can, based on the geo-referenced dataset, produce a quantile map to depict the distribution of rural non-farm enterprise productivity across space in both countries. See Figure 1A and 1B.

From this we can see that rural non-farm enterprise productivity is highest around Tigray, Amhara, Somali and Oromia regions of Ethiopia; and around the northern zones of Nigeria, in addition to the South-South zone. These EAs of high performance appear to be clustered in space, as was expected. 
Figure 1A: Rural non-farm enterprise productivity in Ethiopia

Distribution of RNFE Performance, 2011- Ethiopia

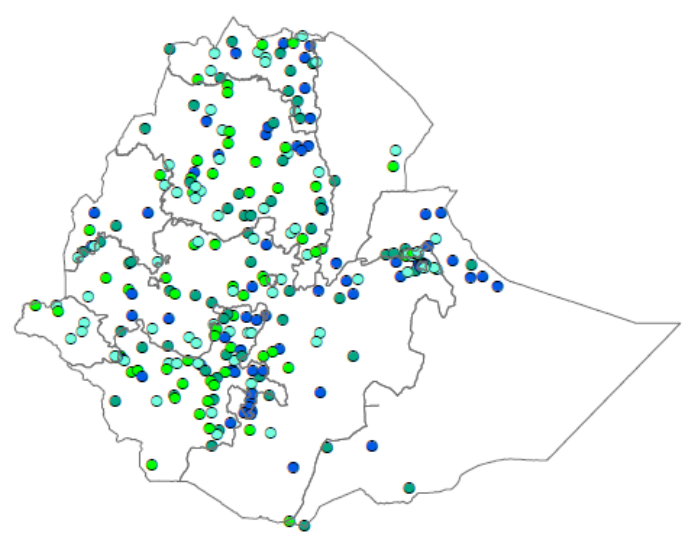

Quantiles

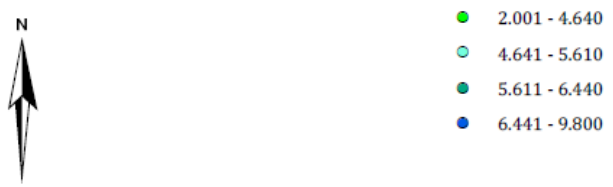

Figure 1B: Rural non-farm enterprise productivity in Nigeria

Distribution of RNFE Performance, 2010/ 2011- Nigeria

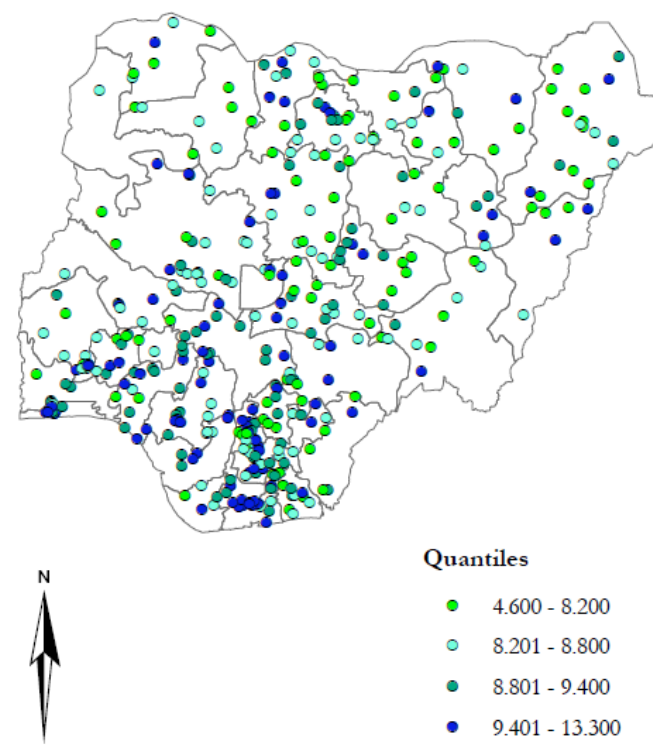


In order to examine the evidence for spatial clustering, Moran's I indices are calculated for rural non-farm enterprise productivity, using a variety of weight matrices in an effort to impose some structure on the data and therefore correct for the observed spatial autocorrelation. A weight matrix is an $N \boldsymbol{x} N$ positive and symmetric matrix which exogenously determines for each observation (row) and which locations (columns) belong in its neighbourhood (Gibson, 2007). Non-neighbours are assigned a weight of 0 while neighbours are assigned a weight of 1 .

An inverse distance weight matrix allows the impact of one enumerator area's productivity on another enumerator area's productivity to decrease with distance. Close neighbours have a larger influence on each other than other neighbours that are more distant. An inverse distance squared weight matrix is the same as above but the slope is sharper so influence drops off more quickly, and only neighbours in closer enumerator areas will exert the most influence.

The third matrix is the fixed distance band weight matrix. Here, a band distance is set so that each enumerator area has at least one (1) neighbour. All enumerator areas within this specified critical distance are included in the analysis; all other enumerator areas outside the critical distance are excluded.

A $K$-nearest neighbour weight matrix is also used. Here, each enumerator area has a fixed number of neighbours who may exert some influence over their rural non-farm enterprise productivity. For this study, 5- and 20- nearest neighbour's weight matrices are used for the Ethiopia dataset, where the closest 5 and 20 enumerator areas are included in the analysis. 5- 40 nearest neighbour's weight matrices are used for the Nigeria dataset.

The Moran's I statistic is a 'global' measure of spatial autocorrelation over the entire sample population, and a positive Moran's I statistic indicates a positive spatial autocorrelation where EAs with high (low) rural non-farm enterprise performance are surrounded by other EAs with similarly high (low) rural non-farm enterprise performance (Anselin, 2005). A negative Moran's I statistic indicates a negative spatial autocorrelation where EAs with high (low) rural non-farm enterprise performance are surrounded by other EAs with low (high) rural non-farm enterprise performance.

Tables 2A and 2B below show that the Moran's I statistic is positive and highly significant under the different weight matrices in both countries. What this means is that a regression of the spatially weighted average of rural non-farm enterprise performance within neighbourhoods (as given by the different weight matrices) on each individual enumerator area would yield a positive and statistically significant co-efficient, indicating the presence of global spatial autocorrelation in the data.

Table 2A: Global Moran's I Indices and P-Values under Various Weight Matrices- Ethiopia

\begin{tabular}{llll}
\hline Weight Matrix & Moran's I & Z-Scores & P- Value \\
\hline Inverse Distance & 0.097 & 6.41 & 0.000000 \\
Inverse Distance squared & 0.096 & 6.27 & 0.000000 \\
Distance band & 0.165 & 4.66 & 0.000003 \\
5- Nearest Neighbour & 0.130 & 5.25 & 0.000000 \\
20- Nearest Neighbour & 0.097 & 5.71 & 0.000000 \\
\hline
\end{tabular}


Table 2B: Global Moran's I Indices and P-Values under Various Weight Matrices- Nigeria

\begin{tabular}{llll}
\hline Weight Matrix & Moran's I & Z-Scores & P- Value \\
\hline Inverse Distance & 0.056 & 3.66 & 0.000248 \\
Inverse Distance squared & 0.055 & 3.62 & 0.000291 \\
Distance band & 0.056 & 3.71 & 0.000211 \\
5- Nearest Neighbour & 0.112 & 3.83 & 0.000130 \\
20- Nearest Neighbour & 0.076 & 5.30 & 0.000000 \\
30- Nearest Neighbour & 0.062 & 5.73 & 0.000000 \\
40- Nearest Neighbour & 0.061 & 6.23 & 0.000000 \\
\hline
\end{tabular}

Although global spatial autocorrelation has been observed in rural non-farm enterprise performance, it may be useful to examine the presence of spatial autocorrelation in nonfarm enterprise performance at a more localized scale, using the 5 different weight matrices.

Figure 2A and 2B show the results of local 'hot-spot' analysis on rural non-farm enterprise performance, using each of the weight matrices. A 'hot-spot' is an area where there is a high concentration of rural non-farm enterprises. There is evidence of significant positive local spatial autocorrelation in the data. Darker shaded clusters in Figures $2 \mathrm{~A}$ and $2 \mathrm{~B}$ depict enumerator areas with high rural non-farm enterprise productivity, which are surrounded by other enumerator areas with similarly high rural non-farm enterprise productivity; darker red clusters are more significant. Lighter shaded clusters indicate enumerator areas with low rural non-farm enterprise productivity, which are surrounded by similarly low-performing enumerator areas. Darker blue clusters are more significant than lighter blue clusters. 
Figure 2A: 'Hot Spot' analysis of rural non-farm enterprise productivity in Ethiopia

\section{MAP OF ETHIOPIA SHOWING SPATIAL CORRELATION OF RNFE PERFORMANCE, USING VARIOUS WEIGHT MATRICES}
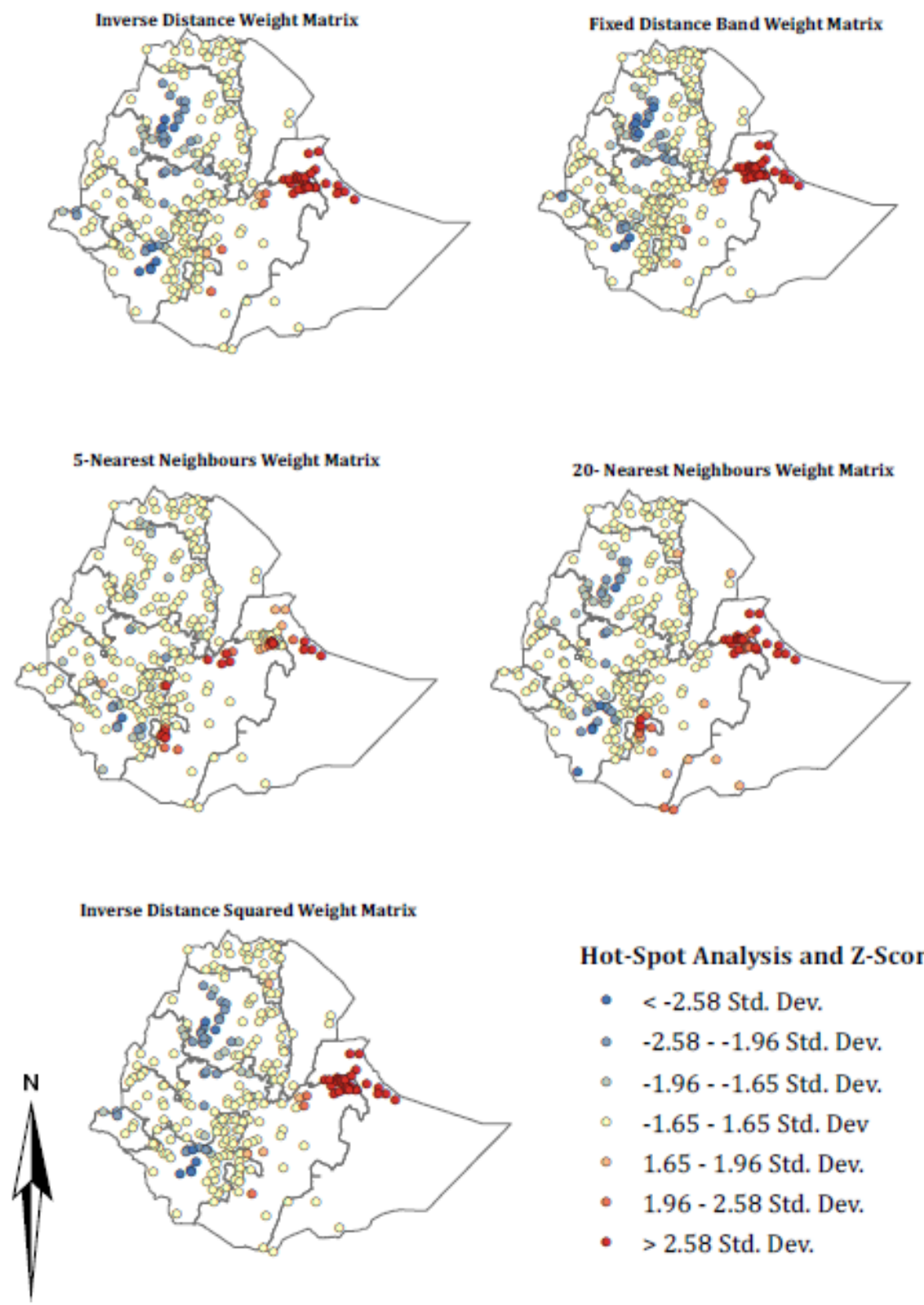

Hot-Spot Analysis and Z-Scores

$-<-2.58$ Std. Dev.

- $\quad-2.58--1.96$ Std. Dev.

- $\quad-1.96--1.65$ Std. Dev.

- $\quad-1.65-1.65$ Std. Dev

- 1.65 - 1.96 Std. Dev.

- $1.96-2.58$ Std. Dev.

- $>2.58$ Std. Dev. 


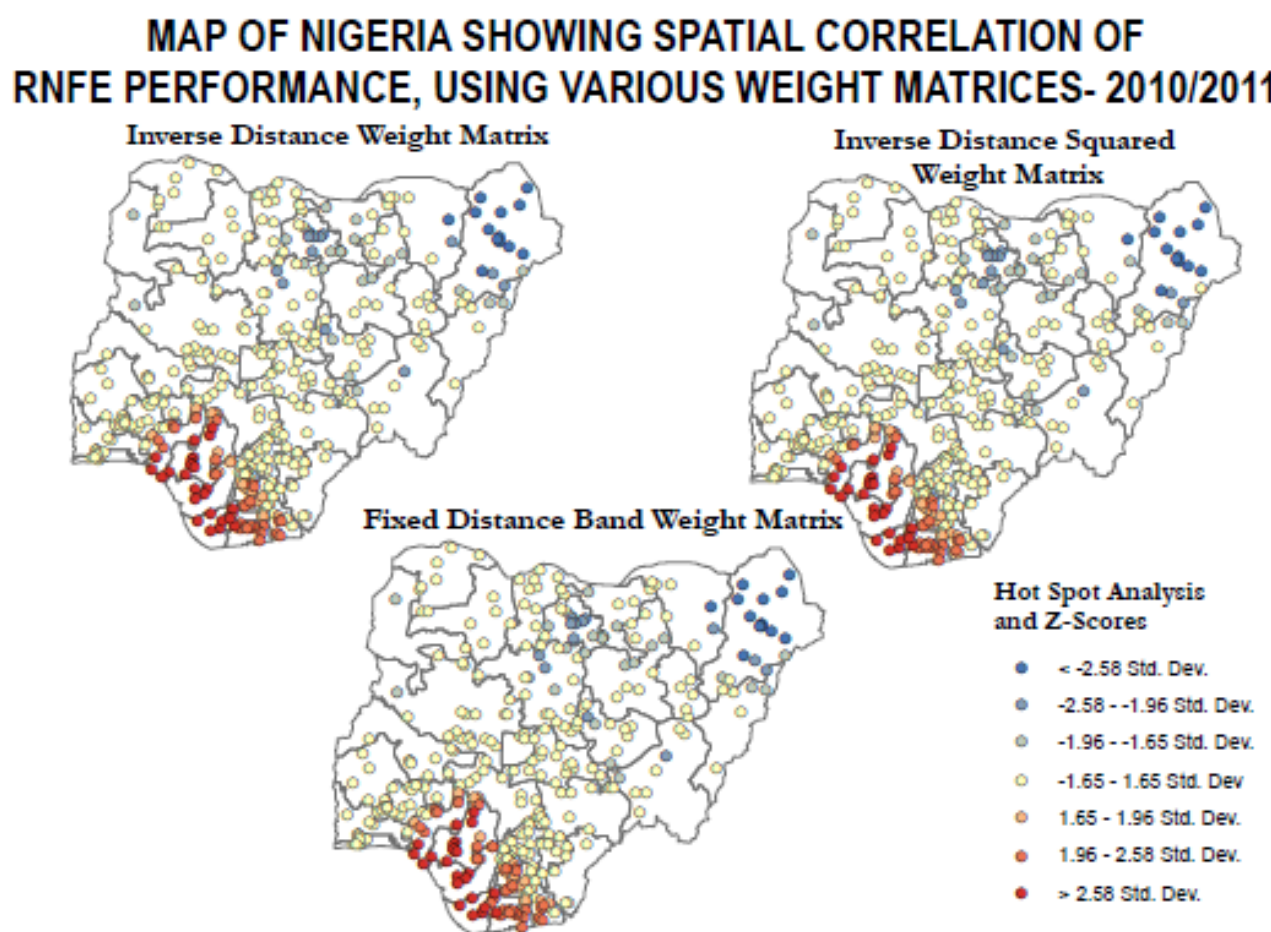

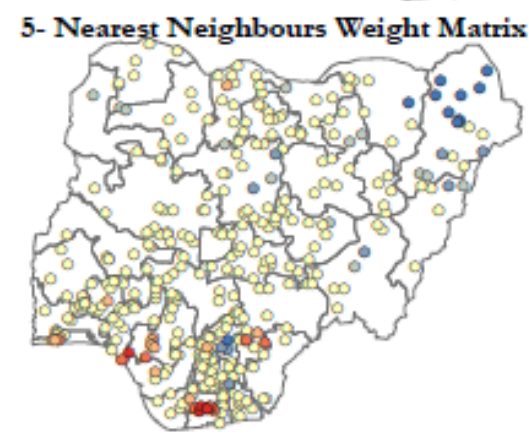

30- Nearest Neighbours Weight Matrix

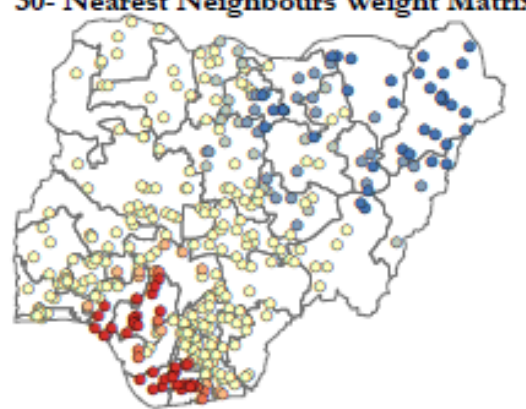

20- Nearest Neighbours Weight Matrix

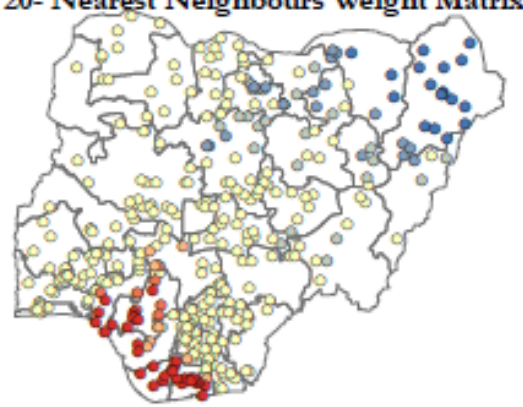

40- Nearest Neighbours Weight Matrix

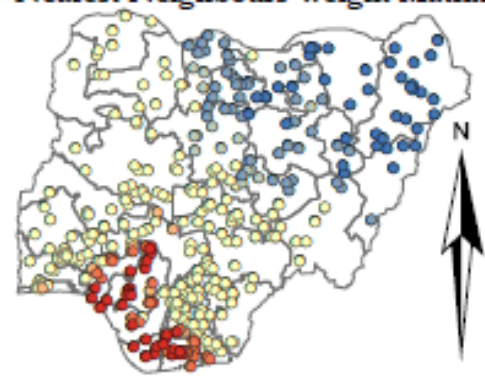

A consistent pattern of rural non-farm enterprise (RNFE) performance is observed across Ethiopia using the various weight matrices. High-performing rural non-farm enterprises appear to be clustered in the Eastern parts of the country, around the Somali and Oromia regions. Low-performing rural non-farm enterprises are clustered around the north-eastern and south-eastern parts of the country, around the Amhara and SNNP regions, although these clusters are not highly significant under the 5 - nearest neighbour weight matrix specification. 
There is a similar situation of spatially differentiated performance levels in Nigeria where a distinct North-South pattern is observable. Non-farm enterprises in the south-western parts of the country (around Rivers state) appear to perform better than enterprises in north-eastern parts of the country (around Borno state). Although the spread of these clusters differ, based on the weight matrix employed, the distinct north-south pattern is still observable.

\section{Regression Results}

\subsection{Estimators}

In the previous section we confirmed evidence of spatial autocorrelation in the data. This spatial autocorrelation may take two forms. First, there could be some spatial dependence in the dependent variable, which would imply that rural non-farm enterprise performance may be influenced by the performance of neighbouring non-farm enterprises. This possibility can be taken care of by a so-called spatial lag model. A second type of spatial autocorrelation can be due to omitted variables in the model that are spatially correlated. A spatial error model should be used to correct for this error bias.

In our regression results, reported in the next subsection, we start by reporting the results of an ordinary least squares (OLS) regression as the base model for the analyses. The basic model is specified as

$$
Y=X \beta+\epsilon
$$

where $Y$ is the dependent variable, $X$ is the vector of household and community

independent variables, $\beta$ is the vector of regression coefficients and $\epsilon$ is the vector of errors.

In order to control for spatial autocorrelation, two other models specifications are employed namely, the spatial lag and the spatial error models.

The spatial lag regression model is in standard notation:

$$
Y=\rho W Y+X \beta+\varepsilon
$$

where the variables are defined as in (1). $\rho$ is the spatial autoregressive parameter and $W Y$ is the spatially lagged dependent variable. The spatial inverse distance weight matrix is used for the analyses, where enumerator areas further away are constrained to matter less for individual EA rural non-farm enterprise performance. This weight matrix is used because it produces the most significant evidence of spatial correlation in the data.

The spatial error model is written as

$$
\begin{aligned}
& Y=X \beta+\varepsilon \\
& \varepsilon=\lambda W \varepsilon+\mu
\end{aligned}
$$

where the variables are as defined in (1). $\boldsymbol{\lambda}$ is the spatial autoregressive parameter and $\boldsymbol{\mu}$ is the vector of errors. In the spatial error model, the error for one enumerator area is 
dependent on the weighted average of the errors in neighbouring enumerator areas, with the strength of this relationship measured by the spatial autoregressive parameter, $\boldsymbol{\lambda}$.

Before proceeding, it is necessary to mention that spatial econometrics, in particular spatial lag models, have been subject to some criticism in recent years, for instance by Partridge et al. (2012), Pinkse and Slade (2010) and McMillan (2010) amongst others. The essence of these criticisms relate to the difficulty of attaching causality to correlation patterns across space. For instance in the present context non-farm enterprises in particular spatial locations may have similar levels of productivity not as a result of spatial spill-over effects, but as a result of a common third factor. In this light therefore, we take care to describe spatial autocorrelations as associations and to include regional/geographic zone control variables in our regression analyses. Additionally, as Corrado and Fingleton (2011) point out, the specification of the weight matrices which are used in the spatial analysis may not necessarily be a true reflection of underlying social and economic processes. Results of these regression analyses are presented and discussed in the next subsection.

\subsection{Regression Results}

The dependent variable, rural non-farm enterprise productivity is regressed on household and community characteristics under three model specifications- OLS, Spatial Lag and Spatial Error. Results of each of the three model specifications of rural non-farm enterprise performance are depicted in Table $3 \mathrm{~A}$ and $3 \mathrm{~B}$ for Ethiopia and Nigeria, respectively. 
Table 3A: OLS, Spatial Lag and Spatial Error Estimates of the Equation for rural non-farm enterprise productivity in Ethiopia, using Community-level data

\begin{tabular}{|c|c|c|c|c|c|}
\hline Variables & OLS & Spatial Lag & Spatial Error & $\begin{array}{l}\text { Spatial Lag } \\
\text { (Regional } \\
\text { Effects) }\end{array}$ & $\begin{array}{l}\text { Spatial Error } \\
\text { (Regional } \\
\text { Effects) }\end{array}$ \\
\hline Age of household head & $\begin{array}{l}-0.006 \\
(-0.61)\end{array}$ & $\begin{array}{l}-0.006 \\
(-0.55)\end{array}$ & $\begin{array}{l}-0.005 \\
(-0.52)\end{array}$ & $\begin{array}{l}-0.007 \\
(-0.66)\end{array}$ & $\begin{array}{c}-0.006 \\
(-0.64)\end{array}$ \\
\hline Male household head & $\begin{array}{l}0.463 \\
(1.14)\end{array}$ & $\begin{array}{l}0.473 \\
(1.21)\end{array}$ & $\begin{array}{l}0.437 \\
(1.12)\end{array}$ & $\begin{array}{l}0.635^{+} \\
(1.60)\end{array}$ & $\begin{array}{l}0.618^{+} \\
(1.52)\end{array}$ \\
\hline Married household head & $\begin{array}{l}-0.675 \\
(-1.60)\end{array}$ & $\begin{array}{l}-0.660^{*} \\
(-1.63)\end{array}$ & $\begin{array}{l}-0.640^{+} \\
(-1.59)\end{array}$ & $\begin{array}{l}-0.678^{*} \\
(-1.69)\end{array}$ & $\begin{array}{l}-0.657^{*} \\
(-1.63)\end{array}$ \\
\hline Educated household head & $\begin{array}{l}1.163^{* * *} \\
(4.34)\end{array}$ & $\begin{array}{l}1.128^{* * *} \\
(4.39)\end{array}$ & $\begin{array}{l}1.160^{* * *} \\
(4.42)\end{array}$ & $\begin{array}{l}1.103^{* * *} \\
(4.09)\end{array}$ & $\begin{array}{l}1.097^{* * *} \\
(4.05)\end{array}$ \\
\hline Muslim household head & $\begin{array}{l}1.068^{* * *} \\
(5.27)\end{array}$ & $\begin{array}{l}0.812^{* * *} \\
(3.89)\end{array}$ & $\begin{array}{l}0.900^{* * *} \\
(3.78)\end{array}$ & $\begin{array}{l}0.814^{* * *} \\
(3.07)\end{array}$ & $\begin{array}{l}0.873^{* * *} \\
(3.24)\end{array}$ \\
\hline Household size & $\begin{array}{l}-0.031 \\
(-0.54)\end{array}$ & $\begin{array}{c}-0.042 \\
(-0.77)\end{array}$ & $\begin{array}{l}-0.031 \\
(-0.55)\end{array}$ & $\begin{array}{l}-0.053 \\
(-0.92)\end{array}$ & $\begin{array}{l}-0.051 \\
(-0.87)\end{array}$ \\
\hline EA has cooperative & $\begin{array}{l}-0.070 \\
(-0.29)\end{array}$ & $\begin{array}{l}-0.050 \\
(-0.22)\end{array}$ & $\begin{array}{l}-0.028 \\
(-0.12)\end{array}$ & $\begin{array}{l}-0.072 \\
(-0.31)\end{array}$ & $\begin{array}{l}-0.069 \\
(-0.30)\end{array}$ \\
\hline EA has phone & $\begin{array}{l}0.025 \\
(0.13)\end{array}$ & $\begin{array}{l}0.077 \\
(0.42)\end{array}$ & $\begin{array}{l}0.076 \\
(0.40)\end{array}$ & $\begin{array}{l}0.136 \\
(0.69)\end{array}$ & $\begin{array}{l}0.139 \\
(0.70)\end{array}$ \\
\hline EA has microfinance inst & $\begin{array}{l}0.137 \\
(0.69)\end{array}$ & $\begin{array}{l}0.126 \\
(0.66)\end{array}$ & $\begin{array}{l}0.123 \\
(0.64)\end{array}$ & $\begin{array}{l}0.096 \\
(0.48)\end{array}$ & $\begin{array}{l}0.105 \\
(0.52)\end{array}$ \\
\hline Distance to asphalt road & $\begin{array}{l}-0.001 \\
(-0.87)\end{array}$ & $\begin{array}{l}-0.0007 \\
(-0.56)\end{array}$ & $\begin{array}{l}-0.0005 \\
(-0.40)\end{array}$ & $\begin{array}{l}-0.001 \\
(-0.81)\end{array}$ & $\begin{array}{l}-0.001 \\
(-0.83)\end{array}$ \\
\hline Distance to market & $\begin{array}{l}-0.0004 \\
(-0.20)\end{array}$ & $\begin{array}{l}-0.00008 \\
(-0.04)\end{array}$ & $\begin{array}{l}-0.0004 \\
(-0.20)\end{array}$ & $\begin{array}{l}-0.001 \\
(-0.25)\end{array}$ & $\begin{array}{l}-0.001 \\
(-0.33)\end{array}$ \\
\hline Afar & - & - & - & $\begin{array}{l}-0.372 \\
(-0.58)\end{array}$ & $\begin{array}{l}-0.366 \\
(-0.56)\end{array}$ \\
\hline Amhara & - & - & - & $\begin{array}{l}-0.058 \\
(-0.20)\end{array}$ & $\begin{array}{l}-0.115 \\
(-0.35)\end{array}$ \\
\hline Oromia & - & - & - & $\begin{array}{l}-0.200 \\
(-0.77)\end{array}$ & $\begin{array}{l}-0.200 \\
(-0.72)\end{array}$ \\
\hline Somali & - & - & - & $\begin{array}{l}0.555 \\
(1.25)\end{array}$ & $\begin{array}{l}0.654 \\
(1.37)\end{array}$ \\
\hline Benishangul & - & - & - & $\begin{array}{l}-0.413 \\
(-0.91)\end{array}$ & $\begin{array}{l}-0.474 \\
(-0.99)\end{array}$ \\
\hline Tigray & - & - & - & $\begin{array}{l}0.317 \\
(1.00)\end{array}$ & $\begin{array}{l}0.325 \\
(0.90)\end{array}$ \\
\hline Gambelia & - & - & - & $\begin{array}{l}-0.157 \\
(-0.31)\end{array}$ & $\begin{array}{c}-0.191 \\
(-0.36)\end{array}$ \\
\hline Harari & - & - & - & $\begin{array}{l}0.266 \\
(0.44)\end{array}$ & $\begin{array}{l}0.691 \\
(1.06)\end{array}$ \\
\hline Diredwa & - & - & - & $\begin{array}{l}-0.588 \\
(-1.04)\end{array}$ & $\begin{array}{l}-0.452 \\
(-0.74)\end{array}$ \\
\hline Constant & $\begin{array}{l}5.443^{* * *} \\
(9.84)\end{array}$ & $\begin{array}{l}1.639 \\
(1.27)\end{array}$ & $\begin{array}{l}5.400^{* * *} \\
(9.02)\end{array}$ & $\begin{array}{l}2.544 \\
(1.52)\end{array}$ & $\begin{array}{l}5.502^{* * *} \\
(8.87)\end{array}$ \\
\hline Rho $(p)$ & - & $\begin{array}{l}0.675^{* * *} \\
(3.25)\end{array}$ & - & $\begin{array}{l}0.527^{*} \\
(1.85)\end{array}$ & - \\
\hline $\operatorname{Lambda}(\boldsymbol{\lambda})$ & - & - & $\begin{array}{l}0.699 * * * \\
(3.08)\end{array}$ & - & $\begin{array}{l}0.310 \\
(0.73)\end{array}$ \\
\hline R-squared & $18.43 \%$ & $19.70 \%$ & $18.20 \%$ & $23.6 \%$ & $22.7 \%$ \\
\hline No. of Observations & 259 & 259 & 259 & 259 & 259 \\
\hline
\end{tabular}


Table 3B: OLS, Spatial Lag and Spatial Error Estimates of the Equation for rural non-farm enterprise productivity in Nigeria, using Community-level data

\begin{tabular}{|c|c|c|c|c|c|}
\hline Variables & OLS & Spatial Lag & Spatial Error & $\begin{array}{l}\text { Spatial Lag } \\
\text { (Regional } \\
\text { Effects) }\end{array}$ & $\begin{array}{l}\text { Spatial Error } \\
\text { (Regional } \\
\text { Effects) }\end{array}$ \\
\hline Age of household head & $\begin{array}{c}-0.0244^{* * *} \\
(-2.85)\end{array}$ & $\begin{array}{c}-0.0245^{* * *} \\
(-2.96)\end{array}$ & $\begin{array}{c}-0.0246^{* * *} \\
(-2.89)\end{array}$ & $\begin{array}{c}-0.0268^{* * *} \\
(-3.14)\end{array}$ & $\begin{array}{c}-0.0270^{* * *} \\
(-3.15)\end{array}$ \\
\hline Male household head & $\begin{array}{c}-1.287^{* *} \\
(-2.16)\end{array}$ & $\begin{array}{c}-1.022^{*} \\
(-1.76)\end{array}$ & $\begin{array}{c}-0.858+ \\
(-1.45)\end{array}$ & $\begin{array}{l}-0.739 \\
(-1.28)\end{array}$ & $\begin{array}{l}-0.762 \\
(-1.30)\end{array}$ \\
\hline Married household head & $\begin{array}{l}0.649 \\
(1.15)\end{array}$ & $\begin{array}{l}0.522 \\
(0.96)\end{array}$ & $\begin{array}{l}0.417 \\
(0.75)\end{array}$ & $\begin{array}{l}0.566 \\
(1.03)\end{array}$ & $\begin{array}{l}0.592 \\
(1.06)\end{array}$ \\
\hline Educated household head & $\begin{array}{c}-1.914^{* *} \\
(-2.43)\end{array}$ & $\begin{array}{c}-1.748^{* *} \\
(-2.29)\end{array}$ & $\begin{array}{c}-1.657^{* *} \\
(-2.15)\end{array}$ & $\begin{array}{c}-1.238+ \\
(-1.61)\end{array}$ & $\begin{array}{c}-1.234+ \\
(-1.60)\end{array}$ \\
\hline Household size & $\begin{array}{c}-0.0478 \\
(-1.17)\end{array}$ & $\begin{array}{c}-0.0232 \\
(-0.58)\end{array}$ & $\begin{array}{c}-0.0130 \\
(-0.30)\end{array}$ & $\begin{array}{c}0.0180 \\
(0.41)\end{array}$ & $\begin{array}{c}0.0174 \\
(0.40)\end{array}$ \\
\hline EA has phone & $\begin{array}{l}0.132 \\
(1.07)\end{array}$ & $\begin{array}{l}0.134 \\
(1.12)\end{array}$ & $\begin{array}{l}0.135 \\
(1.10)\end{array}$ & $\begin{array}{l}0.131 \\
(1.11)\end{array}$ & $\begin{array}{l}0.131 \\
(1.10)\end{array}$ \\
\hline EA has microfinance inst & $\begin{array}{c}0.356^{* *} \\
(2.53)\end{array}$ & $\begin{array}{c}0.342^{* *} \\
(2.51)\end{array}$ & $\begin{array}{c}0.337^{* *} \\
(2.43)\end{array}$ & $\begin{array}{c}0.334^{* *} \\
(2.47)\end{array}$ & $\begin{array}{c}0.337^{* *} \\
(2.49)\end{array}$ \\
\hline Distance to asphalt road & $\begin{array}{c}-0.00220 \\
(-0.68)\end{array}$ & $\begin{array}{c}-0.00109 \\
(-0.34)\end{array}$ & $\begin{array}{c}-0.000908 \\
(-0.27)\end{array}$ & $\begin{array}{c}0.00169 \\
(0.53)\end{array}$ & $\begin{array}{c}0.00168 \\
(0.52)\end{array}$ \\
\hline Distance to market & $\begin{array}{c}0.000778 \\
(0.62)\end{array}$ & $\begin{array}{c}0.000562 \\
(0.46)\end{array}$ & $\begin{array}{c}0.000647 \\
(0.47)\end{array}$ & $\begin{array}{c}-0.000398 \\
(-0.30)\end{array}$ & $\begin{array}{c}-0.000387 \\
(-0.29)\end{array}$ \\
\hline North East Zone & & & & $\begin{array}{c}-0.578^{* * *} \\
(-2.85)\end{array}$ & $\begin{array}{c}-0.629 * * * \\
(-3.26)\end{array}$ \\
\hline North West Zone & & & & $\begin{array}{c}-0.559^{* * *} \\
(-2.84)\end{array}$ & $\begin{array}{c}-0.593^{* * *} \\
(-3.02)\end{array}$ \\
\hline South East Zone & & & & $\begin{array}{c}0.0180 \\
(0.08)\end{array}$ & $\begin{array}{c}0.0403 \\
(0.18)\end{array}$ \\
\hline South South Zone & & & & $\begin{array}{l}0.175 \\
(0.86)\end{array}$ & $\begin{array}{l}0.218 \\
(1.10)\end{array}$ \\
\hline South West Zone & & & & $\begin{array}{c}0.0659 \\
(0.32)\end{array}$ & $\begin{array}{c}0.0956 \\
(0.47)\end{array}$ \\
\hline Constant & $\begin{array}{c}10.72^{* * *} \\
(16.98)\end{array}$ & $\begin{array}{c}3.888^{* *} \\
(2.19)\end{array}$ & $\begin{array}{c}10.24^{* * *} \\
(14.80)\end{array}$ & $\begin{array}{c}8.121^{* * *} \\
(2.77)\end{array}$ & $\begin{array}{c}10.25^{* * *} \\
(15.89)\end{array}$ \\
\hline Rho $(p)$ & - & $\begin{array}{c}0.747^{* * *} \\
(4.10)\end{array}$ & - & $\begin{array}{l}0.240 \\
(0.74)\end{array}$ & \\
\hline $\operatorname{Lambda}(\boldsymbol{\lambda})$ & & & $\begin{array}{c}0.748^{* * *} \\
(3.83)\end{array}$ & & $\begin{array}{c}0.0263 \\
(0.07)\end{array}$ \\
\hline R-squared & 0.091 & 0.104 & 0.085 & 0.154 & 0.152 \\
\hline No. of Observations & 379 & 379 & 379 & 379 & 379 \\
\hline
\end{tabular}

Using household heads that have not had any schooling as the base group, education is found to be significantly correlated with rural non-farm enterprise performance across all three model specifications in Ethiopia (Huffman, 1980).

Rural non-farm enterprises in enumerator areas with a higher fraction of household heads that have had some education appear to perform about 113 to 116 per cent better than rural non-farm enterprise with household heads that have had no education at all. In Nigeria, heads that are currently enrolled in school appear to perform worse than household heads that are not.

The results in Table 3A also show that Muslims-owned rural non-farm enterprises in rural Ethiopia appear to perform significantly better than non-Muslim owned rural nonfarm enterprises. This may be evidence of the importance of religious social capital in rural non-farm enterprise performance and particular specializations in trade among the Muslim population. The magnitude of these religious effects is however less, but still significant, once spatial effects are controlled for, suggesting that the spatial distribution of Muslim households play a major role in explaining rural non-farm enterprise performance in Ethiopia. This confirms that models which do not explicitly correct for 
spatial dependence would over-estimate the importance of religious affiliation in explaining rural non-farm enterprise performance in Ethiopia.

The results in Table 3B indicates that in Nigeria, rural non-farm enterprises headed by males perform significantly worse than female non-farm entrepreneurs, although this is not the case anymore once regional controls are included.

Other determinants of rural non-farm enterprise performance in Ethiopia include the age of the household head and the household size. Although not significant in Ethiopia, an additional year of age is correlated with a $2.4 \%$ decrease in non-farm enterprise performance in Nigeria. Age has been used as a proxy for experience in the literature, and is expected to be positively correlated with enterprise performance (Evans and Leighton 1989; Bregger, 1996; Robson 1998; Rupasingha and Contreras, 2010; Frazer, 2005).

In Nigeria, non-farm entrepreneurs who have access to a microfinance institution perform about a third better entrepreneurs who do not have access to these institutions, demonstrating the importance of credit and community infrastructure in non-farm enterprise performance.

Spatial parameters rho and lambda in the spatial lag and error model specifications, respectively, are positive and statistically significant. These might be indicative of the presence of positive spill-over effects, or perhaps a communal move to switch from farming- to non-farm activities, although one has to be careful to assign such spill-over effects given the shortcomings of spatial lag models mentioned in the previous subsection. A significant spatial lag co-efficient implies some degree of interaction among rural nonfarm enterprise in the enumeration areas, while a significant spatial error co-efficient (lambda) implies that there are some spatially correlated omitted variables which influence rural non-farm enterprise performance in Ethiopia and Nigeria. These findings are consistent with similar studies conducted in developed countries (Gibson and Olivia, 2007; Rupasingha and Contreras, 2010; Baumgartner et al., 2012). The magnitude of other explanatory variables is smaller once spatial effects are controlled for, implying that models which do not account for the spatial nature of the data may over-estimate the effects of such exogenous factors in the model.

The inclusion of regional control variables however changes these initially observed spatial results. In the spatial error model, Lambda is no longer significant when regional effects are controlled for in Ethiopia; however, although the significance of rho is diminished with the inclusion of regional controls, the spatial lag parameter remains positive and significant. In Nigeria, lambda and rho are no longer significant, although still positive, once geographical zones are controlled for.

The presence of a positive and significant rho is indicative of possible diffusion processes, where performances of enterprises in a location predict an increased likelihood of similar performances in neighbouring places. The presence of a positive and significant lambda is indicative of omitted (spatially correlated) covariates that have the potential to affect inference, if left unattended. Lambda is no longer significant in either country-model once regional controls are included- implying that performance of rural non-farm enterprises varies regionally in both countries. This may be observed from the initial quantile maps of both countries in Figures 1A and 1B. Rho, however, remains significant in Ethiopia after regional controls are controlled for, indicating the presence of a diffusion process, 
possibly through technical and knowledge transfers and/or information exchanges between business enterprises in Ethiopia.

In Tables 4A and 4B present results from the estimation of non-farm enterprise performance using individual-level data on household heads in both Nigeria and Ethiopia. The inverse distance weight matrix is used to define the spatial relationships among household heads in the various EAs.

Table 4A: OLS, Spatial Lag and Spatial Error Estimates of the equation for rural non-farm enterprise productivity in Ethiopia, using Individual level data

\begin{tabular}{|c|c|c|c|}
\hline Variables & OLS & Spatial Lag & $\begin{array}{l}\text { Spatial } \\
\text { Error }\end{array}$ \\
\hline Age of household head & $\begin{array}{l}-0.010^{* * *} \\
(-2.74)\end{array}$ & $\begin{array}{l}-0.013^{* * *} \\
(-4.20)\end{array}$ & $\begin{array}{l}-0.015^{* * *} \\
(-4.78)\end{array}$ \\
\hline Male household head & $\begin{array}{l}0.277^{*} \\
(1.72)\end{array}$ & $\begin{array}{l}0.364^{* * * *} \\
(2.72)\end{array}$ & $\begin{array}{l}0.409^{* * * *} \\
(3.15)\end{array}$ \\
\hline Married household head & $\begin{array}{c}-0.161 \\
(-0.98)\end{array}$ & $\begin{array}{l}-0.222^{*} \\
(-1.63)\end{array}$ & $\begin{array}{l}-0.226^{*} \\
(-1.70)\end{array}$ \\
\hline Educated household head & $\begin{array}{l}0.339^{* * * *} \\
(3.19)\end{array}$ & $\begin{array}{l}0.155^{*} \\
(1.75)\end{array}$ & $\begin{array}{l}0.054 \\
(0.59)\end{array}$ \\
\hline Muslim household head & $\begin{array}{l}0.491^{* * *} \\
(3.54)\end{array}$ & $\begin{array}{l}0.296^{* * *} \\
(2.56)\end{array}$ & $\begin{array}{l}0.358^{* * * *} \\
(2.47)\end{array}$ \\
\hline Household size & $\begin{array}{l}-0.047^{* *} \\
(2.08)\end{array}$ & $\begin{array}{l}-0.047^{* * *} \\
(-2.50)\end{array}$ & $\begin{array}{l}-0.049^{* * *} \\
(-2.62)\end{array}$ \\
\hline EA has cooperative & $\begin{array}{l}0.111 \\
(0.86)\end{array}$ & $\begin{array}{l}0.074 \\
(0.69)\end{array}$ & $\begin{array}{l}0.156 \\
(0.75)\end{array}$ \\
\hline EA has phone & $\begin{array}{l}0.138 \\
(1.12)\end{array}$ & $\begin{array}{c}-0.079 \\
(0.77)\end{array}$ & $\begin{array}{l}0.174 \\
(0.94)\end{array}$ \\
\hline EA has microfinance inst & $\begin{array}{l}0.174^{+} \\
(1.47)\end{array}$ & $\begin{array}{l}0.075 \\
(0.76)\end{array}$ & $\begin{array}{l}0.086 \\
(0.46)\end{array}$ \\
\hline Distance to asphalt road & $\begin{array}{l}-0.003^{* * *} \\
(-4.02)\end{array}$ & $\begin{array}{l}-0.002^{* * *} \\
(-2.54)\end{array}$ & $\begin{array}{l}-0.002^{*} \\
(-1.76)\end{array}$ \\
\hline Distance to market & $\begin{array}{l}0.0006 \\
(0.48)\end{array}$ & $\begin{array}{l}-0.00001 \\
(-0.01)\end{array}$ & $\begin{array}{l}-0.0007 \\
(-0.34)\end{array}$ \\
\hline Afar & $\begin{array}{l}-1.120 * * * \\
(-2.65)\end{array}$ & $\begin{array}{c}-0.550^{+} \\
(-1.56)\end{array}$ & $\begin{array}{l}-0.686 \\
(-1.06)\end{array}$ \\
\hline Amhara & $\begin{array}{c}-0.089 \\
(-0.53)\end{array}$ & $\begin{array}{c}-0.119 \\
(-0.86)\end{array}$ & $\begin{array}{l}-0.359 \\
(-1.34)\end{array}$ \\
\hline Oromia & $\begin{array}{c}-0.297^{*} \\
(-1.88)\end{array}$ & $\begin{array}{c}-0.182 \\
(-1.38)\end{array}$ & $\begin{array}{l}-0.300 \\
(-1.20)\end{array}$ \\
\hline Somali & $\begin{array}{l}1.115^{\text {*** }} \\
(4.04)\end{array}$ & $\begin{array}{l}0.518^{* *} \\
(2.25)\end{array}$ & $\begin{array}{l}0.685^{*} \\
(1.72)\end{array}$ \\
\hline Benishangul & $\begin{array}{l}0.209 \\
(0.98)\end{array}$ & $\begin{array}{l}-0.026 \\
(-0.15)\end{array}$ & $\begin{array}{l}-0.056 \\
(-0.15)\end{array}$ \\
\hline Tigray & $\begin{array}{l}0.149 \\
(0.80)\end{array}$ & $\begin{array}{l}0.042 \\
(0.27)\end{array}$ & $\begin{array}{l}0.061 \\
(0.19)\end{array}$ \\
\hline Gambelia & $\begin{array}{c}-0.314 \\
(-0.93)\end{array}$ & $\begin{array}{c}-0.131 \\
(-0.47)\end{array}$ & $\begin{array}{c}-0.479 \\
(-0.92)\end{array}$ \\
\hline Harari & $\begin{array}{l}1.140^{* * * *} \\
(3.61)\end{array}$ & $\begin{array}{l}0.483^{*} \\
(1.83)\end{array}$ & $\begin{array}{l}1.144^{* *} \\
(2.29)\end{array}$ \\
\hline Diredwa & $\begin{array}{l}-0.882^{* * * *} \\
(-3.51)\end{array}$ & $\begin{array}{l}-0.455^{* *} \\
(-2.17)\end{array}$ & $\begin{array}{l}-0.912^{* *} \\
(-2.22)\end{array}$ \\
\hline Constant & $\begin{array}{l}5.883^{* * * *} \\
(22.68)\end{array}$ & $\begin{array}{l}2.975^{* * *} \\
(11.74) \\
(1.27)\end{array}$ & $\begin{array}{l}6.378^{* * * *} \\
(20.57)\end{array}$ \\
\hline Rho $(p)$ & - & $\begin{array}{l}0.572^{* * *} \\
(21.77)\end{array}$ & - \\
\hline $\operatorname{Lambda}(\boldsymbol{\lambda})$ & - & - & $\begin{array}{l}0.582^{* * *} \\
(21.91)\end{array}$ \\
\hline R-squared & $13.08 \%$ & $12.40 \%$ & $11.80 \%$ \\
\hline No. of Observations & 1,230 & 1,230 & 1,230 \\
\hline
\end{tabular}


Table 4B: OLS, Spatial Lag and Spatial Error Estimates of the Equation for rural non-farm enterprise productivity in Nigeria, using Individual level data

\begin{tabular}{|c|c|c|c|}
\hline Variables & OLS & Spatial Lag & Spatial Error \\
\hline Age of household head & $-0.0125^{* * *}$ & $-0.0125^{* * *}$ & $-0.0126^{* * *}$ \\
\hline & $(-5.10)$ & $(-5.11)$ & $(-5.13)$ \\
\hline Male household head & 0.0255 & 0.0408 & 0.0616 \\
\hline & $(0.17)$ & $(0.27)$ & $(0.41)$ \\
\hline Married household head & -0.00496 & -0.0145 & -0.0221 \\
\hline & $(-0.03)$ & $(-0.10)$ & $(-0.15)$ \\
\hline Educated household head & -0.0691 & -0.0427 & -0.0256 \\
\hline & $(-0.31)$ & $(-0.20)$ & $(-0.12)$ \\
\hline Household size & -0.0170 & -0.0163 & -0.0164 \\
\hline & $(-1.37)$ & $(-1.33)$ & $(-1.33)$ \\
\hline EA has phone & $\begin{array}{c}0.135^{*} \\
(1.69)\end{array}$ & $\begin{array}{c}0.124+ \\
(1.57)\end{array}$ & $0.139+$ \\
\hline EA has microfinance inst & $0.240^{* * *}$ & $0.213^{* *}$ & $0.242^{* *}$ \\
\hline Distance to asphalt road & $\begin{array}{c}(1.00251 \\
(1.13)\end{array}$ & $\begin{array}{c}(2.42) \\
0.00228 \\
(1.04)\end{array}$ & $\begin{array}{c}(2.46) \\
0.00255 \\
(1.03)\end{array}$ \\
\hline Distance to market & $\begin{array}{c}-0.00158^{*} \\
(-1.86)\end{array}$ & $\begin{array}{c}-0.00136+ \\
(-1.62)\end{array}$ & $\begin{array}{c}-0.00150+ \\
(-1.57)\end{array}$ \\
\hline North East Zone & $\begin{array}{c}-0.517^{* * * *} \\
(-4.03)\end{array}$ & $\begin{array}{c}-0.465^{* * *} \\
(-3.65)\end{array}$ & $\begin{array}{c}-0.527^{* * * *} \\
(-3.66)\end{array}$ \\
\hline North West Zone & $\begin{array}{c}-0.752^{* * *} \\
(-6.27)\end{array}$ & $\begin{array}{c}-0.664^{* * *} \\
(-5.51)\end{array}$ & $\begin{array}{c}-0.752^{* * *} \\
(-5.58)\end{array}$ \\
\hline South East Zone & $\begin{array}{c}-0.240^{*} \\
(-1.76)\end{array}$ & $\begin{array}{c}-0.209+ \\
(-1.54)\end{array}$ & $\begin{array}{c}-0.231+ \\
(-1.52)\end{array}$ \\
\hline South South Zone & $\begin{array}{c}0.190+ \\
(1.56)\end{array}$ & $\begin{array}{l}0.166 \\
(1.38)\end{array}$ & $\begin{array}{l}0.193 \\
(1.42)\end{array}$ \\
\hline South West Zone & $\begin{array}{c}-0.0549 \\
(-0.46)\end{array}$ & $\begin{array}{c}-0.0521 \\
(-0.44)\end{array}$ & $\begin{array}{c}-0.0545 \\
(-0.41)\end{array}$ \\
\hline Constant & $\begin{array}{c}9.694^{* * * *} \\
(46.69)\end{array}$ & $\begin{array}{c}8.480^{* * * *} \\
(24.37)\end{array}$ & $\begin{array}{c}9.665^{* * * *} \\
(44.82)\end{array}$ \\
\hline Rho $(p)$ & - & $\begin{array}{c}0.133^{* * *} \\
(4.32)\end{array}$ & - \\
\hline Lambda $(\boldsymbol{\lambda})$ & & & $0.136^{* * *}$ \\
\hline & - & - & $(4.39)$ \\
\hline R-squared & 0.068 & 0.068 & 0.068 \\
\hline No. of Observations & 2,001 & 2,001 & 2,001 \\
\hline
\end{tabular}

Results are largely similar to those observed in Tables 3A and 3B, although more coefficients are highly significant when the sample size is increased. For instance, in Ethiopia, male household-heads appear to perform better than female heads across all the model specifications. Additionally, rural non-farm enterprise performance decline with distance from tarred and asphalt roads, meaning that physical infrastructure is an important determinant of rural non-farm enterprise performance. In Nigeria, more community infrastructure variables- access to phones and distance to market- become important in determining non-farm enterprise performance.

A major difference of this disaggregated analysis is that with the inclusion of regional controls, the spatial lag and error coefficients in both countries remain highly significant, indicating the presence of spatial autocorrelation e at the individual level. As mentioned earlier however, the partial results reported here are subject to the shortcomings of the random GIS assignment process.

In Table 3A and 3B, at the more aggregated scale, the spatial lag model appears to fit slightly better than the spatial error model, in terms of R-squared, both before and after the inclusion of regional controls in both countries. This is confirmed in Table 5A and 5B below where the log-likelihoods of each of the spatial models are compared. Similar to the 
R-squared value, a higher log-likelihood is indicative of a better model fit, and these values are higher under the spatial lag, than under the spatial error models.

Table 5A: Log-Likelihood Values for Spatial Regression Models with Inverse Distance Spatial Weight Matrices- Ethiopia

\begin{tabular}{lr}
\hline \multicolumn{2}{c}{ Log- Likelihood Tests for Spatial models } \\
\hline Spatial Lag (with regional controls) & -435.16 \\
Spatial Lag (wit & -430.57 \\
Spatial Error ( & -436.19 \\
Spatial Error (with regional controls) & -431.70 \\
\hline
\end{tabular}

Table 5B: Log-Likelihood Values for Spatial Regression Models with Inverse Distance Spatial Weight Matrices- Ethiopia

\begin{tabular}{lc}
\hline \multicolumn{2}{c}{ Log- Likelihood Tests for Spatial models } \\
\hline Spatial Lag (with regional controls) & -521.571 \\
Spatial Lag (with & -513.405 \\
Spatial Error & -522.997 \\
Spatial Error (with regional controls) & -513.666 \\
\hline
\end{tabular}

Results of the spatial analyses, especially at the individual level where social interactions and influence are more common, provide some evidence that the local environment is important for rural non-farm enterprise performance through perhaps knowledge spillover effects, collective learning, and backward and forward linkages with local markets. According to Haggblade et al. (2002), rural non-farm enterprises who are engaged in similar activities may cluster together in order to take advantage of larger markets for labour and consumption goods, scale economies, lower energy costs and external economies of agglomeration.

\subsection{Spatial Correlations between Farming and Non-Farming}

As we mentioned in the introduction the importance of the links between non-farm and farming activities have been noted in the literature (e.g. de Janvry et al., 2005; Lanjouw and Lanjouw, 2001). Success in agriculture may generate surpluses for investment in offfarm activities and vice-versa, so that one may see a positive correlation between farm and non-farm productivity. Indeed, as Deichmann et al. (2008:1) declared 'the most predominant view amongst development practitioners about non-farm development is that growth of non-farm activities in rural areas is driven primarily by agriculture productivity growth'.

Given the evidence of significant spatial effects in the data, it is useful to attempt a greater understanding of this relationship. In others words, is the "predominant view amongst development practitioners' supported by the data? Are high performance rural non-farm enterprise clustered, not necessarily to be near one another, but to be near clusters of high productivity farming areas?

In the ERSS data, only about 20 per cent of the survey respondents report that they are engaged in farming activities. In the NGHS however, almost $90 \%$ of the sample are engaged in agriculture. A preliminary ESDA of spatial interactions between the prevalence of farming activities in communities in both countries and the performance of rural non-farm enterprise is provided in Table 6 below. 
Table 6: Global Moran's I Index for Bivariate Relationship between Farming and NonFarm Economies

\begin{tabular}{|l|l|l|}
\hline & Ethiopia & Nigeria \\
\hline Global Moran's I & $-0.0225082^{* *}$ & $-0.0400949^{* * *}$ \\
& $(0.049)$ & $(0.002)$ \\
\hline & & \\
\hline & & \\
\hline
\end{tabular}

A distance-band weight matrix is used for both countries, where every EA is constrained to have at least one neighbour. The Global Moran's I is negative and significant at 5 per cent (significance shown by permutation test in second figure) and 0.01 per cent for Ethiopia and Nigeria, respectively, implying that high (low) performance non-farm enterprises are surrounded by other communities with low (high) engagement in farming activities. It seems that rural non-farm enterprise performance are the highest in low prevalence agricultural areas suggesting that in these regions rural non-farm enterprise are a source of income and security for possibly those households excluded from agricultural activities (see e.g. Lanjouw and Lanjouw, 2001; de Janvry et al. 2005). This finding is surprising as it contradicts the findings elsewhere the literature, for instance in Haggblade et al. (2002) and Deichmann et al. (2008; 2009) and the 'predominant view among development practitioners' mentioned above.

These results must however be interpreted with caution, given the small sample size of the study (239 and 379 observations in Ethiopia and Nigeria, respectively). It may be worthwhile to pursue a further examination of this relationship, using a broader dataset, including greater detail on the type of rural nonfarm activities undertaken, in order to better understand the spatial linkages between rural non-farm enterprise performance and activities of the agricultural sector.

\section{Concluding Remarks}

In recent years there has been a growing interest in the contribution of entrepreneurship to development (e.g. Naudé, 2010; 2011) and to rural development in Africa in particular (e.g. Nagler and Naudé, 2014a, 2014b; Rijkers and Costa, 2012). In rural Africa, the vast majority of households are dependent on farming for a livelihood. They engage in both farming but also non-farming activities. The latter has been established to be important for rural household income, generating on average more than 40 per cent of rural household income in Africa.

While much research has gone into understanding the patterns of rural non-farm enterprises and their contribution to household income and to poverty alleviation, as well as into understanding the determinants of rural household participation in starting up and running such enterprises (see for instance Nagler and Naudé, 2014) there is still a gap in our knowledge of the performance of rural non-farm enterprises in Africa.

In particular, the performance, especially in terms of productivity of farms in Africa has been extensively studied (e.g. Alene, 2010; Block, 2010); also, a number of studies have dealt with the possible benefits of non-farm enterprises for farm productivity (e.g. Oseni and Winters, 2009). No study has yet dealt with rural non-farm productivity in Africa 
satisfactory, and indeed none has as yet considered controlling for spatial autocorrelation and possible spatial spill-over effects in the performance and productivity of these enterprises.

In this paper we made a modest contribution to addressing these two lacunas. Using appropriately geo-referenced rural household data from Ethiopia and Nigeria we studied the determinants of rural non-farm enterprise performance and examined evidence for spill-over effects among non-farm enterprise clusters.

We established that spatial autocorrelation is significant. This means that studies into the determinants of rural enterprises in Ethiopia and Nigeria that omit controlling for spatial dependence / agglomeration effects will be subject to biased estimates. Hence we used appropriately specified regression models to estimate the key determinants of the productivity of rural non-farm enterprises, using sales per worker as our (crude) productivity / performance measure.

From these we found that in Ethiopia high (low)-productivity rural non-farm enterprises were surrounded by other high (low)-productivity rural non-farm enterprises. This confirms the existence and benefits of clusters. It suggests that interaction between households and enterprises may be indeed beneficial as had been expected. Results of a spatial error model initially indicated that there was the presence of some spatiallycorrelated omitted variables. The inclusion of regional controls however removes this spatial dependence, in terms of the spatially correlated errors in the model. The spatial lag parameter remains significant even with the inclusion of regional controls, and the model appears to be a better fit than the spatial error model.

For Nigeria we found that spatial parameters were no longer significant in explaining non-farm enterprise performance, once location controls were included in the model. However, spatial parameters remained significant in both countries, even after regional controls were included, when the analysis is done at the individual level.

Furthermore, we found a negative relationship between rural non-farm enterprise performance and agricultural activity in Ethiopia and Nigeria, implying that increases in farm productivity are not necessarily associated with increases in non-farm enterprise productivity in the same region - it may be that in areas with high agricultural productivity, higher wages reduces the competitiveness of non-farm enterprises. This result runs counter to the 'most prominent view amongst development practitioners' (Deichmann et al., 2008:1) and requires more research, for instance to establish if this is due to the type of rural non-farm enterprise, to wages in agriculture, or to some other unexplained characteristic of rural non-farm enterprises in Africa.

Together, these findings finally allow us to draw some modest policy conclusions. First, investment in local infrastructure, i.e. improvements in the local business environment in rural areas, will support the performance of non-farm enterprises. Second, literature has long emphasized the importance of asset and knowledge accumulation of existing firms, and this process should be encouraged to the extent that existing firms appear to confer positive externalities on other firms in their neighbourhoods or clusters - increasing proximity is important in this regard. Policies to improve the skills and technology of potentially leading enterprises in the community may then easier spill over on to other proximate enterprises. Finally, the findings are consistent with that of many other papers dealing with enterprise performance that argue for the positive effects of entrepreneurial and management education for enterprise performance. 


\section{Acknowledgements}

Earlier versions of this paper were presented at the Global Development Network's 15th Annual Conference, Accra, Ghana on $20^{\text {th }}$ June 2014, and at the World Bank's Annual Bank Conference on Africa, Paris, France on $24^{\text {th }}$ June 2014. We are grateful to the participants of these conferences for their feedback. We want in particular to acknowledge the useful feedback and encouragement from the participants in the 'Agriculture in Africa: Telling Facts from Myths' project. Luc Christiaensen, Jonathan Kaminski, Paula Nagler, Amparo Palacios-López all provided comments, support and/or direction that contributed towards this paper. The usual disclaimer applies.

\section{References}

Ali, M. and Peerlings, J. (2011). 'Value Added of Cluster Membership for Micro Enterprises of the Handloom Sector in Ethiopia', World Development, 39 (3): 363-374.

Ali, M., Peerlings, J., and Zhang, X. (2010). Clustering as an organizational response to capital market inefficiency: Evidence from handloom enterprises in Ethiopia In: IFPRI discussion papers.

Alene, D.A. (2010). 'Productivity Growth and the Effects of R\&D in African Agriculture', Agricultural Economics, 41(3-4): 223-238.

Anselin, L. (2005). "Exploring Spatial Data with GeoDa: A Workbook." Center for Spatially Integrated Social Science

Anselin, L. and Griffith, D. A. (1988). 'Do Spatial Effects really matter in Regression Analysis? Papers in Regional Science, 65: 11-34.

Ayele, G., Chamberlin, J., Moorman,L., Wamisho, K. and Zhang, X. (2009). 'Infrastructure and Cluster Development: A Case Study of Handloom Weavers in Ethiopia', Ethiopia Strategy Support Program, Discussion Paper No. ESSP2 001

Barrett, C., Reardon, T., and Webb, P. (2001). 'Non-Farm Income Diversification and Household Livelihood Strategies in Rural Africa: Concepts, Issues, and Policy Implications', Food Policy, 26 (4):315-331.

Baumgartner, D., Schulz, T. and Seidl, I. (2012). 'Quantifying entrepreneurship and its impact on local economic performance: A spatial assessment in rural Switzerland, Entrepreneurship and Regional Development, DOI:10.1080/08985626.2012.710266

Bernard, A. B., Redding S. J. and Schott, P. K. (2010) Multi-Product Firms and Product Switching, American Economic Review, 100(1), 70-97.

Block, S. (2010). 'The Decline and Rise of Agricultural Productivity in Sub-Saharan Africa since 1961', NBER Working Paper 16481

Bloom, N., and Van Reenen, J. (2010). 'Why do Management Practices Differ Across Firms and Countries?', Journal of Economic Perspectives, 24 (1): 203-224.

Bloom, N., Schankerman, M. and Van Reenen, J. (2013). 'Identifying Technology Spillovers and Product Market Rivalry', Econometrica, 81 (4): 1347-1393. 
Bregger, J. (1996). 'Measuring self-employment in the United States', Monthly Lab. Rev. 119:3-9.

Corrado, L. and Fingleton, B. (2011). 'Where is the Economics in Spatial Econometrics? Spatial Econometrics Research Centre, Discussion Paper 71

De Brauw, A., Mueller, V. And Lim Lee, H. (2013). 'The Role of Rural-Urban Migration in the Structural Transformation of Sub-Saharan Africa', World Development, early online, November 2013.

De Janvry, A. Sadoulet, E, and Zhu, N. (2005). The Role of Non-Farm Incomes in Reducing Rural Poverty and Inequality in China. UC Berkeley: Department of Agricultural and Resource Economics, UCB. Retrieved from: http://www.escholarship.org/uc/item/7ts2z766

Deichmann, U., Shilpi, F., and Vakis, R. (2008).'Spatial Specialization and FarmNonfarm Linkages', World Bank Policy Research Working Paper no. 4611. Washington DC: The World Bank.

Deichmann, U., Shilpi, F., and Vakis, R. (2009). 'Urban Proximity, Agricultural Potential and Rural Non-Farm Employment: Evidence from Bangladesh', World Development, 37 (3): 645-660.

Deller S. C. (2010). 'Spatial Variations in the role of Microenterprises in Economic Growth', The Review of Regional Studies, 40 (1): 71- 97.

ESSP-II (Ethiopian Strategy Support Program II (2009). "Urbanization and Spatial Connectivity in Ethiopia." Research Note No. 5

Evans, D. S. and L. S. Leighton. 1989, "The Determinants of Changes in US SelfEmployment, 1968-87." Small Business Economics 1: 1-19.

Foster, L., Haltiwanger, J. and Syverson, C. (2008). 'Reallocation, Firm Turnover, and Efficiency: Selection on Productivity and Profitability?' American Economic Review, 98(1):394-425.

Fox, L. and Sohnesen, T. (2013). Household Enterprises in Mozambique: Key to Poverty Reduction but not on the Development Agenda? Policy Research Working Paper 6570, Washington DC: The World Bank.

Frazer, G. (2005). 'Which Firms Die? A Look at Manufacturing Firm Exit in Ghana', Economic Development and Cultural Change, 53 (3): 585-617.

Fujita, M., Krugman, P. and Venables, A.J. (1999). The Spatial Economy: Cities, Regions and International Trade. Cambridge MA: MIT Press.

Gibson, J. and Olivia, S. (2007). Spatial Autocorrelation and Non-Farm Rural Enterprise in Indonesia, Selected Paper prepared for presentation at the Australian Agricultural and Resource Economics Society Annual Conference, Queenstown, NZ, February 14-16

Gibson, J. and Olivia, S. (2010). 'The Effects of Infrastructure Access and Quality on Non-Farm Enterprises in Rural Indonesia', World Development, 38 (5): 717-726.

Haggblade, S., Hazell, P. and Reardon, T. (2002). 'Strategies for Stimulating PovertyAlleviating Growth in the Rural Non-Farm Economy in Developing Countries', EPTD Discussion Paper, No. 92. 
Haggblade, S., Hazell, P. and Reardon, T. (2010). 'The Rural Non-farm Economy: Prospects for Growth and Poverty Reduction', World Development, 38(10), 1429-1441.

Janvry, A. D. and Sadoulet, E. (2010). Agriculture for Development in Africa: Businessas-Usual or New Departures? Journal of African Economies, 19 (AERC Supplement 2):ii7-11:39.

Lanjouw, J.O., and Lanjouw, P. (2001). 'The Rural Non-Farm Sector: Issues and Evidence from Developing Countries', Agricultural Economics, 26 (1): 1-23.

Mano, Y., Iddrisu, A., Yoshino, Y. and Sonobe, T. (2012). 'How can Micro and Small Enterprises in Sub-Saharan Africa Become More Productive? The Impacts of Experimental Basic Managerial Training', World Development, 40 (3): 458-468.

Martin, P., Mayer, J. and Mayneris, F. (2011). 'Spatial Concentration and Plant-Level Productivity in France', Journal of Urban Economics, 69: 182-195.

McCormick, D. (1999). 'African Enterprise Clusters and Industrialization', World Development, 27 (9): 1531-1551.

McMillan, D.P. (2010). 'Issues in Spatial Data Analysis', Journal of Regional Science, 50 (1): 119-141.

Moretti, E. (2004). 'Workers' Education, Spillovers, and Productivity: Evidence from Plant-Level Production Functions', American Economic Review, 94 (3): 656-690.

Nagler, Paula and Naudé, Wim (2014a). 'Non-farm Entrepreneurship in Rural Africa: Patterns and Determinants', IZA Discussion Paper no. 8008, Bonn: IZA, Institute for the Study of Labour.

Nagler, Paula and Naudé, Wim (2014b). 'Performance and Survival of Non-Farm Enterprises in Rural Africa: Evidence from the LSMS-ISA Surveys', Paper presented at the $A B C A$, Paris, 23 June.

Naudé, W. (2010). 'Entrepreneurship, Developing Countries and Development Economics: New Approaches and Insights', Small Business Economics Journal, 34 (1): 112 .

Naudé, W. (2011). 'Entrepreneurship is not a Binding Constraint on Growth and Development in the Poorest Countries', World Development, 39 (1), 33-44.

Nichter, S. and Goldmark, L. (2009). 'Small Firm Growth in Developing Countries', World Development, 37 (9): 1435-1464.

Oseni, G. and Winters, P. (2009). 'Rural Nonfarm Activities and Agricultural Crop Production in Nigeria', Agricultural Economics, 40(2): 189-201.

Partridge, M.A., Boarnet, M., Brakman, S. And Ottaviano, G. (2012). 'Introduction: Whither Spatial Econometrics?', Journal of Regional Science, 52 (2): 167-171.

Pinkse, J. and Slade, M.E. (2010). 'The Future of Spatial Econometrics', Journal of Regional Science, 50 (1): 103-117. 
Reardon, T., Berdegue, J., Barrett, C., and Stamoulis, K. (2006). Household Income Diversification into Rural Non-Farm Activities. Baltimore: Johns Hopkins University Press.

Rijkers, B. and Costa, R. (2012). 'Gender and Rural Non-Farm Entrepreneurship', World Development, Vol. 40, No. 12, pp. 2411- 2426

Rijkers, B. and Söderbom, M. (2013). "The Effects of Risk and Shocks on Non-Farm Enterprise Development in Rural Ethiopia." World Development, Vol. 45, pp. 119- 136

Rijkers, B., Soderbom, M., and Loening, J.L. (2010). 'A Rural-Urban Comparison of Manufacturing Enterprise Performance in Ethiopia', World Development, 38 (9): 12781296.

Rupasingha, A. and Contreras, S. (2010). 'Factors Affecting Spatial Variation of Microenterprises in the Rural U.S', Paper prepared for presentation at the conference on "Economic Development in Underserved Communities: Where Research and Practice Meet", sponsored by the Federal Reserve Bank of Kansas City

Siba, E., Söderbom, M., Bigsten, A., and Gebreeyesus, M. (2012). 'Enterprise Agglomeration, Output Prices and Physical Productivity: Firm-Level Evidence from Ethiopia', UNU-WIDER Research Paper WP2012/85.

Steinberg, S., Steinberg, S. L., Barnes, J. and Keeble, S. (2010). 'Socio Spatial Network Analysis for Rural Economic Development', ASPRS, San Diego, California

Syverson, C. (2011). 'What Determines Productivity?' Journal of Economic Literature, 49 (2): 326-365.

Van Biesebroeck, J. (2005). 'Exporting Raises Productivity in Sub-Saharan Manufacturing Firms', Journal of International Economics, 67 (2): 373-391.

Wennberg, K. and Lindqvist, G.(2010). 'The Effects of Clusters on the Survival and Performance of New Firms', Small Business Economics, 34: 221-241. 